\title{
EXPERIMENTAL STUDY AND ANALYSIS OF THE WEAR PROPERTIES OF FRICTION-STIR-WELDED AA7075-T6 AND A384.0-T6 DISSIMILAR ALUMINIUM ALLOYS OF BUTT JOINTS
}

\author{
EKSPERIMENTALNA ŠTUDIJA IN ANALIZA OBRABE ZVAROV, \\ IZDELANIH Z ROTACIJSKIM TORNIM VARJENJEM \\ RAZNOVRSTNIH ZLITIN AA7075-T6 IN A384.0-T6
}

\author{
Karuppannan Anganan', Subramaniam Prabagaran², Mayakrishnan Muthukrishnan ${ }^{3}$ \\ ${ }^{1}$ Karpagam Academy of Higher Education, Coimbatore, Department of Mechanical Engineering, 641021 Tamil Nadu, India \\ ${ }^{2}$ Karpagam Academy of Higher Education, Department of Mechanical Engineering, Coimbatore, 641021 Tamil Nadu, India \\ ${ }^{3}$ Kalaignar Karunanidhi Institute of Technology, Department of Mechanical Engineering, Coimbatore, 641402 Tamil Nadu, India \\ anganan09@gmail.com \\ Prejem rokopisa - received: 2017-07-06; sprejem za objavo - accepted for publication: 2017-10-11
}

doi:10.17222/mit.2017.109

\begin{abstract}
The wear is one of the main issues in friction-stir welding (FSW) of dissimilar aluminium alloys. Two dissimilar metals welded with FSW have different mechanical, metallurgical and chemical properties compared to the parent materials. Therefore, the wear resistance is an important property in an FSW process. In this research, AA7075-T6 and A384.0-T6 aluminium alloys with a thickness of $6.35 \mathrm{~mm}$ were selected and a design matrix was developed to produce FSW welds using the MINITAB-17 software. Friction-stir-welded pieces were made as test specimens and their ultimate tensile strengths (UTSs) were tested. In these experiments, the maximum- and minimum-UTS specimens were used for a wear-resistance analysis and its results were compared with the wear resistance of the parent metals. The results were obtained by keeping the revolutions per minute $\left(\mathrm{min}^{-1}\right)$, time and sliding velocity as constants, while varying the load applied. The rpm, time and sliding velocity were 500,300 $\mathrm{s}$ and $3.141 \mathrm{~m} / \mathrm{s}$, respectively. The loads applied were $(20,40$ and 60$) \mathrm{N}$. The conclusion is that, under all the applied loads, the wear of the friction-stir weld produced is lower than that of the A384.0-T6 aluminium base metal. On the other hand, the wear of the weld is higher than the AA7075-T6 aluminium base metal.

Keywords: wear resistance, dissimilar aluminium alloys, friction-stir welding, base metals, wear-resistance parameters
\end{abstract}

Obraba raznovrstnih aluminijevih zlitin je ena od glavnih tem v raziskavah na področju rotacijskega tornega varjenja (FSW; angl.: Friction Stir Welding). Dve različni kovini, ki ju varimo, imata med FSW različne mehanske, metalurške in kemične lastnosti v primerjavi s sorodnimi materiali. Odpornost proti obrabi je pomembna lastnost v FSW-procesu. V tej raziskavi so avtorji izbrali dve Al zlitini AA7075-T6 in A384.0-T6 debeline 6,35 mm in z njima oblikovali matrico za FSW-zvare z uporabo programske opreme MINITAB-17. Izdelali so vzorce varjene s postopkom FSW in določili natezno trdnost zvarov. Nato so za nadaljnje preiskave obrabe izbrali vzorce z najmanjšo in največjo natezno trdnostjo in jih primerjali z FSW-zvari, izdelanimi iz sorodnih materialov. Med eksperimenti so držali konstantne naslednje procesne parametre varjenja: število obratov na minuto $\left(500 \mathrm{~min}^{-1}\right)$, čas $(300 \mathrm{~s})$ in hitrost drsenja $(3,141 \mathrm{~m} / \mathrm{s})$; spreminjali pa so obremenitev $(20,40$ in 60$)$ N. Avtorji so v tej raziskavi ugotovili, da je obrabna obstojnost zvarov, izdelanih z FSW drugačna od obrabe zvarov izdelanih iz osnovne Al zlitine A384.0-T6 pri vseh obremenitvah. Obrabna obstojnost izdelanih zvarov iz izbranih nesorodnih zlitin pa je primerljiva z zvari izdelanimi iz Al zlitine AA7075-T6.

Ključne besede: odpornost proti obrabi, raznovrstne Al zlitine, rotacijsko torno varjenje, osnovne kovine, parametri obrabne odpornosti

\section{INTRODUCTION}

FSW is one of the solid-state fumeless welding techniques. It was invented, developed and patented in 1991 by Wayne Thomas, The Welding Institute, United Kingdom. ${ }^{1}$ For our experiment, the plates to be welded were placed adjacent to each other and tightly clamped by a specially made fixture. A tool was fitted to a chuck and that was then fitted to the spindle of an FSW machine. Figure 1 depicts the FSW machine. A rotating tool with an axial pressure force and longitudinal movement was inserted between the two plates. Hence, as a stirring action takes place between the plates, heat is developed and the metals are plastically deformed and joined together. ${ }^{2}$ The concept of an FSW process is shown in Figure 2. After the FSW process, the mechanical, metallurgical, thermal and chemical properties are changed compared to the parent-material properties. In this research, the wear properties were analysed.

L. Guo et al. ${ }^{3}$ investigated the lubrication effect of annealed Fe78Si9B13 glass particles in the FSW of the AA6061 metal and found that the particles play an important role in improving the wear resistance. S. K. Naimuddin et al. ${ }^{4}$ conducted an experimental study analysis of similar and dissimilar joints of the materials of (AA6061-AA6061), (AA6082-AA6082) \& (AA6061-AA6082) under T6 conditions to find the wear behaviours. They found low wear and low wear resistance in the FSW welds. A. M. Hassan et al. ${ }^{5}$ experimentally studied the wear characteristics of aluminium- 
Table 1: Chemical compositions of the base metals

\begin{tabular}{|c|c|c|c|c|c|c|c|c|c|c|}
\hline Metals/ elements & $\mathrm{Mg}$ & $\mathrm{Mn}$ & $\mathrm{Pb}$ & $\mathrm{Zn}$ & $\mathrm{Fe}$ & $\mathrm{Cu}$ & $\mathrm{Si}$ & $\mathrm{Cr}$ & $\mathrm{Ni}$ & $\mathrm{Al}$ \\
\hline AA7075-T6 & 2.29 & 0.047 & 0.004 & 5.44 & 0.20 & 1.45 & 0.071 & 0.24 & 0.006 & Balance \\
\hline A384.0-T6 & 0.11 & 0.24 & 0.54 & 1.83 & 0.96 & 1.54 & 10.15 & 0.031 & 0.099 & Balance \\
\hline
\end{tabular}

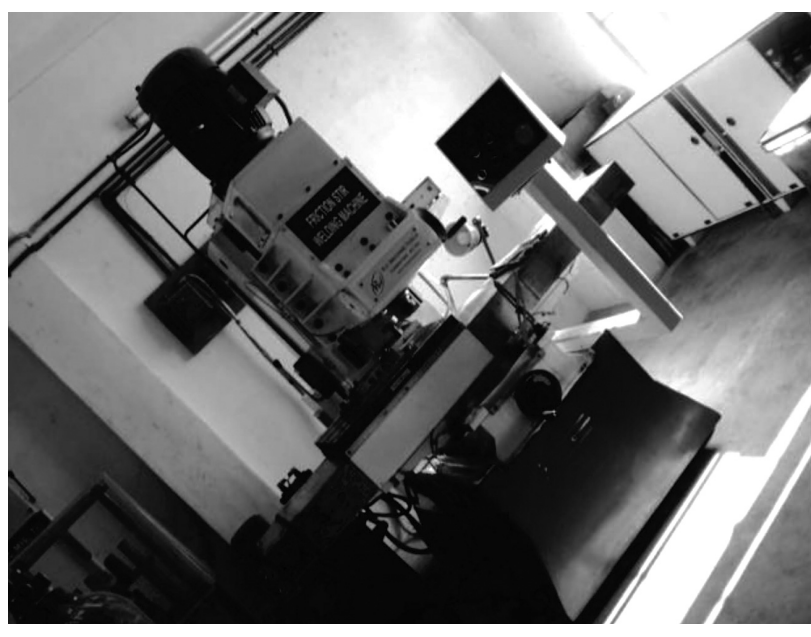

Figure 1: FSW machine

matrix composites reinforced with graphite and silicon carbide particles using FSW techniques. The results showed that the process parameters greatly influenced the wear resistance of the welded joints.

S. Prabagaran et al. ${ }^{7}$ experimentally proved that the formation of the oxides at the interface plays a significant role in reducing the wear rate. To take decisions about FSW weld quality, many welding parameters like tool rotational speed, welding feed, axial load, tool pin profile, etc., are considered. ${ }^{8}$ Many researchers are very interested in optimizing the FSW process parameters. ${ }^{9}$ At the same time, most of the researchers analyse the FSW tool-design parameters with regard to the welding strength of the joints. ${ }^{10-13}$ R. Kumar et al. ${ }^{14}$ experimentally studied the wear characteristics and defects after the

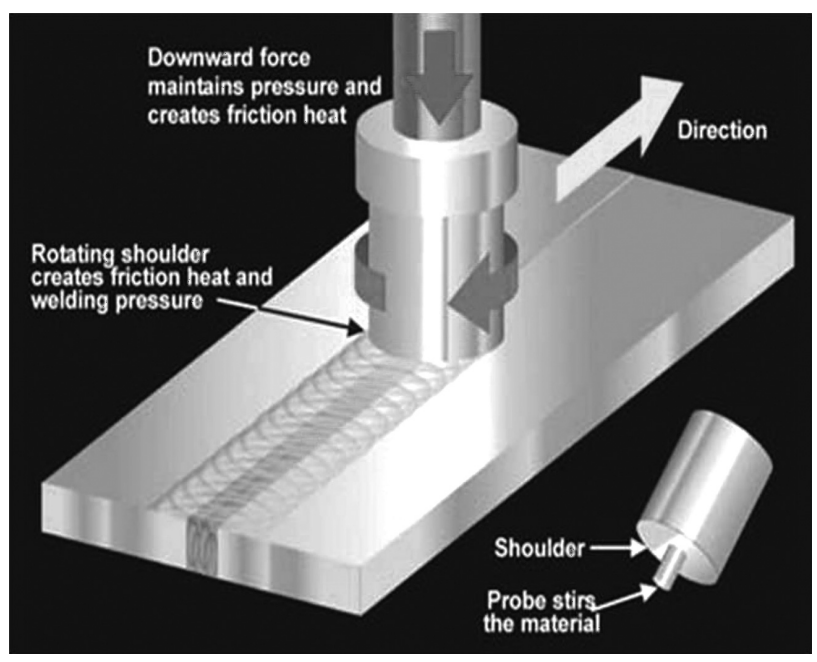

Figure 2: FSW process principle ${ }^{6}$
FSW of AA6061-T6 aluminium alloys using different tool rotational speeds and welding speeds. They concluded that the wear resistance of the FSW joints increased compared to the base material.

\section{EXPERIMENTAL SET-UP}

In this research, the selected base materials were wrought aluminium AA7075-T6 and cast aluminium A384.0-T6 with a $6.35-\mathrm{mm}$ thickness. Aluminium and its alloys have low densities and high strength-to-weight ratios. As a result, these materials are used in various fields. ${ }^{15,16}$ The wrought AA7075-T6 aluminium with a $6.35-\mathrm{mm}$ thickness was purchased and machined to dimensions of $(100 \times 50 \times 6.35) \mathrm{mm}$ using a circular saw machine. The A384.0-T6 aluminium was cast as an ingot and machined to dimensions of $100 \times 50 \times 6.35 \mathrm{~mm}$ using a saw machine and lathe. The chemical compositions and mechanical properties of the parent materials were tested and tabulated in Table $\mathbf{1}$ and Table $\mathbf{2}$, respectively.

Table 2: Mechanical properties of the base metals

\begin{tabular}{|c|c|c|c|c|}
\hline Base metals & $\begin{array}{c}\text { UTS } \\
(\mathrm{MPa})\end{array}$ & $\begin{array}{c}\text { YS } \\
(\mathrm{MPa})\end{array}$ & $\begin{array}{c}\text { Elongation } \\
(\%)\end{array}$ & $\begin{array}{c}\text { Hardness } \\
(\mathrm{HRB})\end{array}$ \\
\hline AA7075-T6 & 581.1 & 379.8 & 11.7 & 92.0 \\
\hline A384.0-T6 & 102.0 & - & 1.0 & 35.8 \\
\hline
\end{tabular}

Table 3: Welding parameters

\begin{tabular}{|c|c|c|c|c|c|c|c|}
\hline Process & Unit & \multirow{2}{*}{$\begin{array}{c}\text { Sym- } \\
\text { bol }\end{array}$} & \multicolumn{5}{|c|}{ Levels } \\
\cline { 4 - 9 } & & -1.682 & -1 & 0 & 1 & 1.682 \\
\hline $\begin{array}{c}\text { Tool rotational } \\
\text { speed }\end{array}$ & $\mathrm{min}^{-1}$ & $\mathrm{~N}$ & 600 & 680 & 800 & 920 & 1000 \\
\hline Welding speed & $\mathrm{mm} / \mathrm{min}$ & $\mathrm{S}$ & 30 & 35 & 40 & 46 & 50 \\
\hline Axial load & $\mathrm{kN}$ & $\mathrm{F}$ & 6 & 6.8 & 8 & 9.2 & 10 \\
\hline
\end{tabular}

A design matrix was developed using the MINITAB-17 software with 3 variables and 5 levels. The welding parameters, or the variables selected for this research, were the tool rotational speed in $\mathrm{min}^{-1}$, the welding speed in $\mathrm{mm} / \mathrm{min}$ and the axial load in kilo newton. These are shown in Table 3. After making different FSW welds as per the design matrix, the ultimate tensile strength (UTS) was tested and its values were tabulated in Table 4.

As seen in Table 4, the minimum UTS for Run Number 5 was $246.33 \mathrm{MPa}$. The maximum UTS for Run Number 10 was $277.37 \mathrm{MPa}$. These two FSW welds were taken for further analysis of the wear resistance; Runs 5 and 10 were also re-designated as W-1 and W-2, respectively. The wear rates for $\mathrm{W}-1$ and $\mathrm{W}-2$ were 
analysed and compared with the wear resistance of the parent materials, viz., AA7075-T6 and A384.0-T6. The removal of the material from the solid surfaces of a solid-state contact is known as the wear.

Table 4: Design matrix and the UTS results in MPa

\begin{tabular}{|c|c|c|c|c|}
\hline \multirow{2}{*}{ Run no. } & \multicolumn{3}{|c|}{ Design matrix } & \\
\cline { 2 - 5 } & \multicolumn{2}{|c|}{ FSW process parameters } & UTS \\
\hline & $\mathrm{N}$ & $\mathrm{F}$ & $\mathrm{S}$ & $\mathrm{MPa}$ \\
\hline 1 & -1 & 1 & -1 & 252.80 \\
\hline 2 & 0 & 0 & 0 & 272.96 \\
\hline 3 & 1 & -1 & -1 & 260.22 \\
\hline 4 & 1 & -1 & 1 & 255.85 \\
\hline 5 & -1 & -1 & -1 & 246.33 \\
\hline 6 & 1 & 1 & -1 & 267.80 \\
\hline 7 & 1.682 & 0 & 0 & 261.76 \\
\hline 8 & -1.682 & 0 & 0 & 248.06 \\
\hline 9 & 0 & 0 & -1.682 & 260.60 \\
\hline 10 & 1 & 1 & 1 & 277.37 \\
\hline 11 & 0 & 1.682 & 0 & 264.02 \\
\hline 12 & -1 & -1 & 1 & 252.37 \\
\hline 13 & 0 & 0 & 1.682 & 271.67 \\
\hline 14 & -1 & 1 & 1 & 260.94 \\
\hline 15 & 0 & -1.682 & 0 & 248.31 \\
\hline 16 & 0 & 0 & 0 & 271.00 \\
\hline 17 & 0 & 0 & 0 & 271.90 \\
\hline 18 & 0 & 0 & 0 & 272.00 \\
\hline 19 & 0 & 0 & 0 & 272.10 \\
\hline 20 & 0 & 0 & 0 & 271.80 \\
\hline & & & & \\
\hline
\end{tabular}

The wear occurs on the outer surfaces of components. In this research, the pin-on-disk wear-testing method was adopted. The pin-on-disk wear-testing apparatus is shown in Figures 3 and 4. During this tribological test, a stationary disk rubs against the rotating pin while the applied load is constant. ${ }^{17}$ For the normal load range, the frictional-force range of the pin-on-disk apparatus was up to $200 \mathrm{~N}$. The sliding speed was $0.26-12 \mathrm{~m} / \mathrm{s}$ and the disk speed was 100-2000 $\mathrm{min}^{-1}$. The wear-disk diameter was $165 \mathrm{~mm}$ and it was made of the En31 material having a disk hardness of 58-60 HRC. The wear-disk track diameter ranged from $10 \mathrm{~mm}$ to $140 \mathrm{~mm}$. The specimen-pin diameter ranged from $3 \mathrm{~mm}$

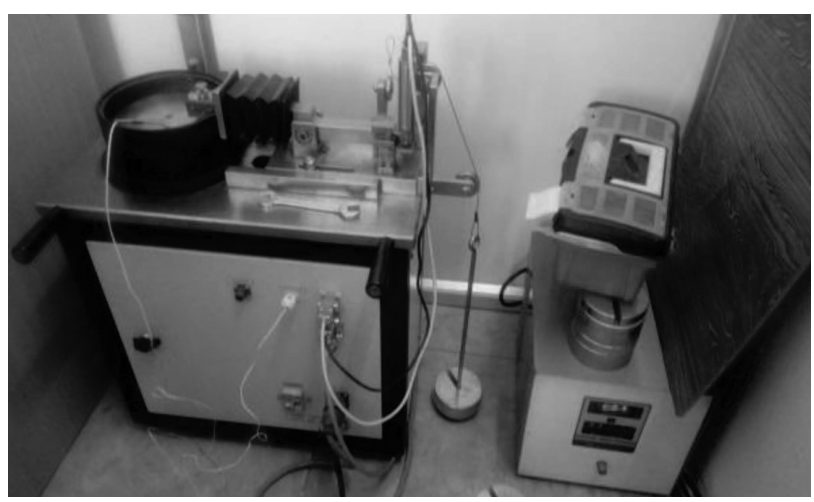

Figure 3: Pin-on-disk wear-test apparatus

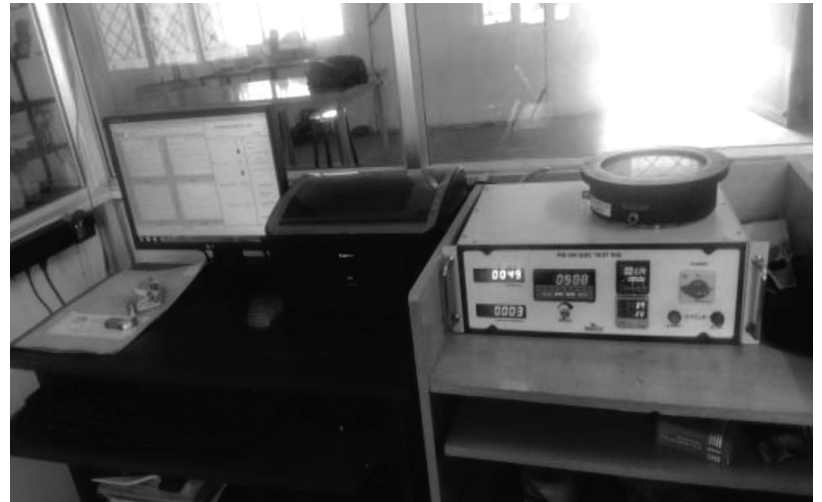

Figure 4: Pin-on-disk wear-test apparatus

to $12 \mathrm{~mm}$ and the length of the specimen pin ranged from 25 to $30 \mathrm{~mm}$.

The dimensions of the specimen prepared for this research were $(30 \times 12 \times 6.35) \mathrm{mm}$; the specimen consisted of the base metals AA7075-T6 and A384.0-T6. In the case of the dissimilar combination, the minimum and maximum UTSs were obtained for welded plates $\mathrm{W}-1$ and W-2, whose weld-nugget areas were used as specimens for the wear test. The experimental wear tests were conducted under dry sliding conditions at normal atmospheric temperature and pressure. Figures 5 and 6 depict the respective wear-test specimen.

\section{RESULTS AND DISCUSSIONS}

While conducting the wear test, the time and the revolution per minute of the disc were kept constant at $300 \mathrm{~s}$ and $500 \mathrm{~min}^{-1}$, respectively. By varying the mate-

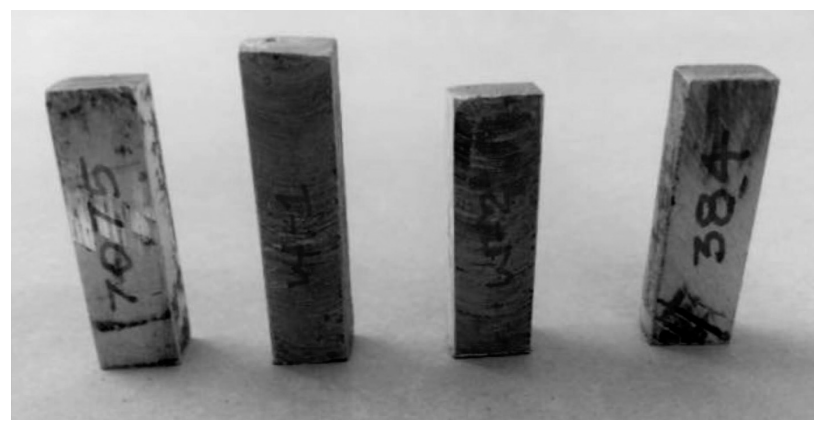

Figure 5: Specimen before the wear test

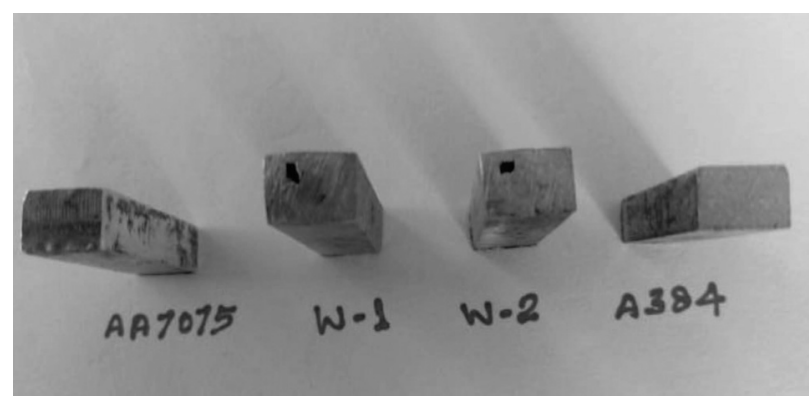

Figure 6: Specimen after the wear test 
rial and the applied loads, the magnitude of the wear in microns was tabulated in Table $\mathbf{5}$.

Using the above table, on the basis of the same applied loads, the materials were segregated and the wear values in microns were discussed. The materials at a $20-\mathrm{N}$ load were grouped in one category and shown in Figure 7 as a bar chart. In this bar chart, the $\mathrm{X}$-axis represents various materials and the Y-axis represents the wear in microns. The wear of the base material A384.0-T6 is higher than that of the base material AA7075-T6 or that of welds W-1 and W-2. This is because the hardness of the base material AA7075-T6 has a high hardness of $92 \mathrm{HRB}$, whereas the base material A384.0-T6 has a low hardness of 35.8 HRB.

The materials at a 40-N load were grouped in another category and shown in Figure $\mathbf{8}$ as a bar chart. In this case, the wear of A384.0-T6 is also higher than that of the base material AA7075-T6 or that of dissimilar weld combinations of AA7075-T6 and A384.0-T6. The materials at a 60-N load were grouped as the third category and shown in Figure $\mathbf{9}$ as a bar chart. In this case, the wear of A384.0-T6 is also higher than that of the base material AA7075-T6 or that of dissimilar weld combinations of AA7075-T6 and A384.0-T6. The wear values for the base material AA7075-T6 and dissimilar friction-stir weld W-2 are more or less the same.

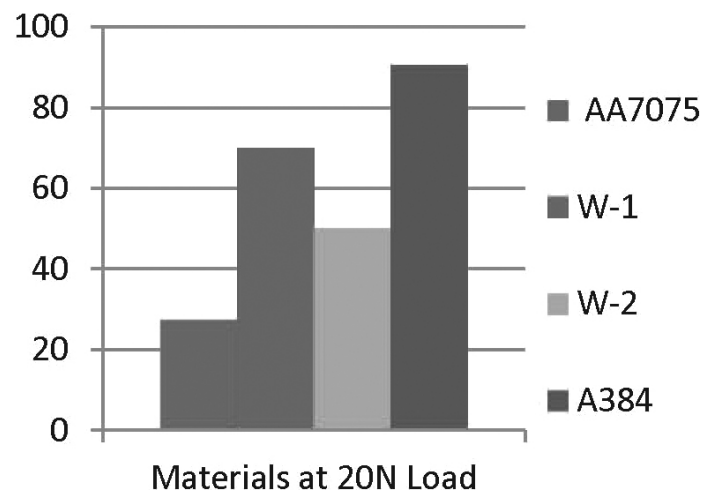

Figure 7: Wear in microns at a load of $20 \mathrm{~N}$

Table 5: Wear values

\begin{tabular}{|c|c|c|c|c|c|c|c|c|}
\hline Sl.no. & Material & $\min ^{-1}$ & Load $(\mathrm{N})$ & Time $(\mathrm{s})$ & $\begin{array}{c}\text { Sliding } \\
\text { velocity }\end{array}$ & $\begin{array}{c}\text { Wear in } \\
\text { microns }\end{array}$ & $\begin{array}{c}\text { COF average } \\
(\mathrm{N}) \text { average }\end{array}$ \\
\hline 1 & 7075 & 500 & 20 & 300 & $3.141 \mathrm{~m} / \mathrm{s}$ & 27.34 & 0.4469 & 8.93 \\
\hline 2 & 7075 & 500 & 40 & 300 & $3.141 \mathrm{~m} / \mathrm{s}$ & 43.07 & 0.3768 & 15.07 \\
\hline 3 & 7075 & 500 & 60 & 300 & $3.141 \mathrm{~m} / \mathrm{s}$ & 38.17 & 0.3538 & 21.23 \\
\hline 4 & $\mathrm{~W}-1$ & 500 & 20 & 300 & $3.141 \mathrm{~m} / \mathrm{s}$ & 70.01 & 0.508 & 10.16 \\
\hline 5 & $\mathrm{~W}-1$ & 500 & 40 & 300 & $3.141 \mathrm{~m} / \mathrm{s}$ & 55.16 & 0.3451 & 13.80 \\
\hline 6 & $\mathrm{~W}-1$ & 500 & 60 & 300 & $3.141 \mathrm{~m} / \mathrm{s}$ & 50.56 & 0.2817 & 16.90 \\
\hline 7 & $\mathrm{~W}-2$ & 500 & 20 & 300 & $3.141 \mathrm{~m} / \mathrm{s}$ & 50.03 & 0.1452 & 2.90 \\
\hline 8 & $\mathrm{~W}-2$ & 500 & 40 & 300 & $3.141 \mathrm{~m} / \mathrm{s}$ & 50.19 & 0.2725 & 10.90 \\
\hline 9 & $\mathrm{~W}-2$ & 500 & 60 & 300 & $3.141 \mathrm{~m} / \mathrm{s}$ & 38.39 & 0.3088 & 18.53 \\
\hline 10 & 384 & 500 & 20 & 300 & $3.141 \mathrm{~m} / \mathrm{s}$ & 90.51 & 0.345 & 6.90 \\
\hline 11 & 384 & 500 & 40 & 300 & $3.141 \mathrm{~m} / \mathrm{s}$ & 63.77 & 0.4156 & 16.62 \\
\hline 12 & 384 & 500 & 60 & 300 & $3.141 \mathrm{~m} / \mathrm{s}$ & 62.46 & 0.3354 & 20.12 \\
\hline
\end{tabular}

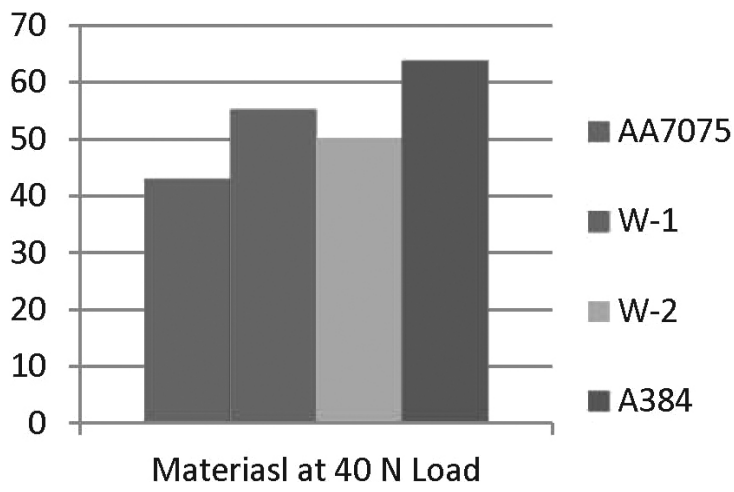

Figure 8: Wear in microns at a load of $40 \mathrm{~N}$

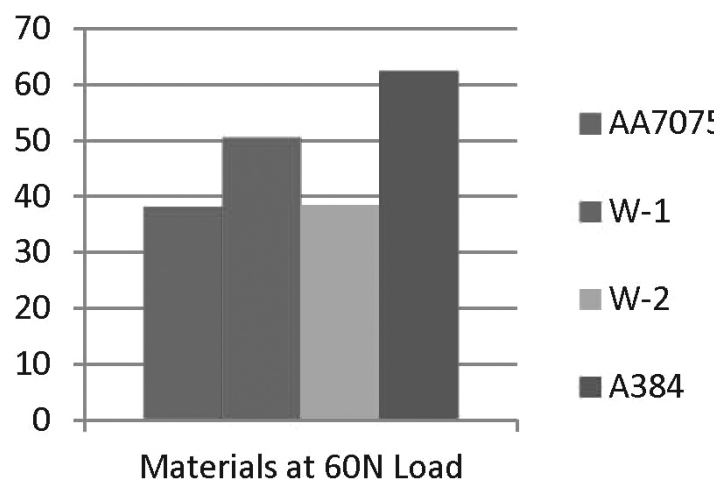

Figure 9: Wear in microns at a load of $60 \mathrm{~N}$
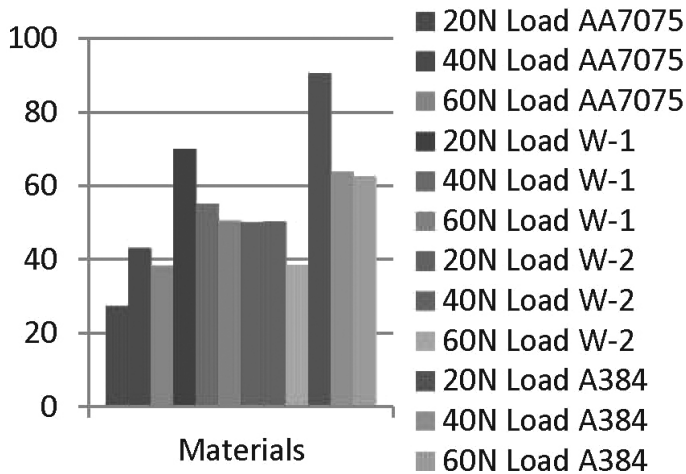

Figure 10: Material wear at (20, 40 and 60) N 
Figure 10 shows the wear in microns of the base material AA7075-T6, welds W-1, W-2 and the base material A384.0-T6 with the applied loads of 20, 40 and $60 \mathrm{~N}$. In the case of the base material AA7075-T6 at the applied loads of 20, 40 and $60 \mathrm{~N}$, the wear was higher at the load of $40 \mathrm{~N}$. In the cases of dissimilar welds W-1, W-2 and the base material A384.0-T6, the wear was reduced if the applied load was increased. This may be due to the increase in the temperature during the wear of the materials.

\section{CONCLUSIONS}

The wear is one of the major mechanical properties of any material. In this research, the base materials were AA7075-T6 and A384.0-T6 aluminium alloys. The wear was discussed and analysed based on the analyses of dissimilar welds combining the AA7075-T6 and A384.0-T6 aluminium materials. The AA7075-T6 aluminium alloy had a high hardness of $92 \mathrm{HRB}$ and the A384.0-T6 aluminium alloy had a hardness of 35.8 HRB. The hardness of FSW welds was between 35.8 and $92 \mathrm{HRB}$. At the same time, the wear was higher for the A384.0-T6 aluminium alloy and lower for the AA7075-T6 aluminium alloy. For the combinations of FSW welds, the wear was between the wear values of the base materials. Therefore, the hardness of materials and the level of wear are inter-related parameters. This was proved in our research.

\section{REFERENCES}

${ }^{1}$ W. M. Thomas, E. D. Nicholas, J. C. Needham, M. G. Murch, P. Templesmith, C. J. Dawes, US Patent 91259788, 1991

${ }^{2}$ G. Minak, L. Ceschini, I. Boromei, M. Ponte, Fatigue properties of friction stir welded particulate reinforced aluminium matrix composites, Int. J. Fatigue, 32 (2010) 1, 218-226

${ }^{3}$ L. Guo, Y. Liu, K. Shen, C. Song, M. Yang, K. Kim, W. Wang, Enhancing Corrosion and Wear Resistance of AA6061 by Friction Stir Processing with Fe78Si9B13 Glass Particles, Materials, 8 (2015), 5084-5097
${ }^{4}$ S. K. Naimuddin, Md T. Ahamad, B. P. C. Sekhar, P. N. Mohan, V. Kampurath, Y. Ali, Wear Behaviour of Welded and Non-Welded Samples of Friction Stir Welding of Similar and Dissimilar Joints of Aluminium Alloys (AA6061-AA6061), (AA6082-AA6082) \& (AA6061-AA6082) under T6 Condition, International Journal of Mechanical Engineering and Technology (IJMET), 7 (2016) 4, 289-299

${ }^{5}$ A. M. Hassan, M. Almomani, T. Qasim, A. Ghaithan, Effect of Processing Parameters on Friction Stir Welded Aluminum Matrix Composites Wear Behavior, Materials and Manufacturing Processes, 27 (2012), 1419-1423

${ }^{6}$ D. Lohwasser, Z. Chen, Friction Stir Welding, Woodhead Pub., 2009

${ }^{7}$ S. Prabagaran, G. Chandramohan, P. Shanmughasundaram, Influence of graphite on the hardness and wear behaviour of AA6061-B4C composite, Materiali in tehnologije / Materials and Technology, 48 (2014) 5, 661-667

${ }^{8}$ R. S. Mishra, Z. Y. Ma, Friction stir welding and processing, Materials Science and Engineering, R 50 (2005), 1-78

${ }^{9}$ S. Vijayan, R. Raju, S. R. K. Rao, Multiobjective optimization of friction stir welding process parameters on aluminum alloy AA5083 using Taguchi-based grey relation analysis, Materials and Manufacturing Processes, 25 (2010), 1206-1212

${ }^{10}$ M. Aissani, S. Gachi, F. Boubenider, Y. Benkedda, Design and optimization of friction stir welding tool, Materials and Manufacturing Processes, 25 (2010), 1199-1205

${ }^{11}$ C. N. Suresh, B. M. Rajaprakas, S. Upadhya, A study of the effect of tool pin profiles on tensile strength of welded joints produced using friction stir welding process, Materials and Manufacturing Processes, 26 (2011) 9, 1111-1116

${ }^{12}$ K. Kumar, S. V. Kailas, T. S. Srivatsan, The role of tool design in influencing the mechanism for the formation of friction stir welds in aluminum alloy 7020, Materials and Manufacturing Processes, 26 (2011) 7, 915-921

${ }^{13}$ Y. H. Yin, N. Sun, T. H. North, S. S. Hu, Influence of tool design on mechanical properties of AZ31 friction stir spot welds, Science and Technology of Welding and Joining, 15 (2010) 1, 81-87

${ }^{14}$ R. Kumar, S. Chattopadhyaya, S. Hloch, G. Krolczyk, S. Legutko, Wear characteristics and defects analysis of friction stir welded joint of aluminium alloy 6061-T6, Eksploatacja i Niezawodnosc Maintenance and Reliability, 18 (2016) 1, 128-135

${ }^{15}$ H. Bakes, D. Benjamin, Metals Handbook, ASM international, Metals Park, OH, USA, 1979

${ }^{16}$ A. K. Vasudevan, R. D. Doherty, Aluminum Alloys - Contemporary Research and Applications, Elsevier, Amsterdam, The Netherlands, 2012

${ }^{17}$ D. M. Kennedy, M. S. J. Hashmi, Methods of wear testing for advanced surface coatings and bulk materials, Journal of Materials Processing Technology, 77 (1998), 246-253 